Noticias

CAMPOS SULINOS

\section{Planícies recheadas de biodiversidade}

Grandes extensões de terras planas ou levemente onduladas, com arbustos baixos e vegetação rasteira. Esta é a principal característica dos campos sulinos, localizados no bioma Pampa, na porção sul e oeste do Rio Grande do Sul, e nas partes mais altas do planalto sul-brasileiro, onde predomina o bioma Mata Atlântica. Os campos sulinos são ecossistemas naturais, ou seja, eles já existiam na região sul do Brasil muito antes da expansão das formações florestais. Atualmente, porém, enfrentam grande degradação em virtude da expansão da monocultura da soja e da silvicultura. Conforme levantamentos do geógrafo Henrich Hasenack, professor da Universidade Federal do Rio Grande do Sul, as perdas já são de $60 \%$.

CAMPOS FÉRTEIS EM BIODIVERSIDADE A aparente monotonia das planícies contrasta com os altos índices de biodiversidade: considerando os 174 mil quilômetros quadrados de campos originais no estado do Rio Grande do Sul, existem 2,6 mil tipos de plantas vasculares (que possuem tecidos especializados para transportar o alimento para as células). Outra característica marcante dos campos sulinos é o alto grau de endemismo (quando uma espécie ocorre em uma área geográfica única) da flora da região: cerca de 500 plantas são endêmicas, ou seja, crescem

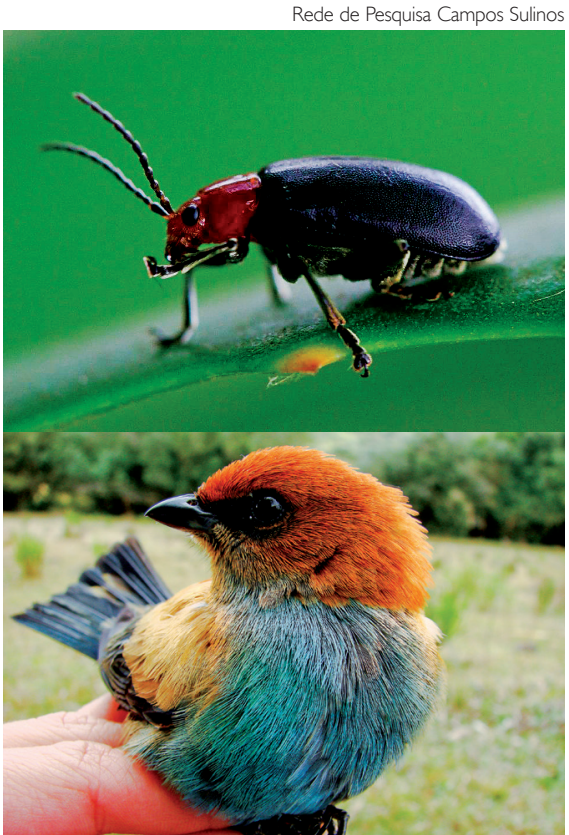

Campos sulinos têm alto grau de plantas e animais endêmicos

somente no Rio Grande do Sul. O alto grau de biodiversidade e de endemismo são resultado da combinação de influências das florestas tropicais, situadas no Brasil Central, e das floras temperadas originárias do sul da América do Sul.

A fauna dos campos sulinos também merece destaque: só na parte brasileira (esse ecossistema se estende pelo Uruguai e Argentina) são conhecidas 480 variedades de aves e cerca de 90 de mamíferos. Além disso, mais de uma centena de aves e pelo menos 25 espécies de mamíferos estão intimamente associados aos habitats campestres. Considerando tanto a parte brasileira do bioma Pampa como os campos do planalto sul brasileiro, são conhecidas 21 variedades endêmicas de vertebrados, número que deve aumentar com novas descobertas. A maior parte desses endemismos é exclusiva dos campos planálticos do bioma Mata Atlântica, ocorrendo do nordeste do Rio Grande do Sul até os campos gerais do Paraná. Os vertebrados endêmicos dos campos do sul do Brasil incluem cinco tipos de peixes, oito de sapos, rãs e pererecas, quatro de répteis (três serpentes e um lagarto), três de aves e uma de mamífero.

SERVIÇOS AMBIENTAIS Os campos sulinos prestam também importantes serviços ambientais: eles são a principal fonte forrageira para a atividade pastoril, um dos pilares da economia do Rio Grande do Sul; conservam recursos hídricos superficiais e subterrâneos, além de oferecer beleza cênica com grande potencial turístico.

Para estudar esse ecossistema, e os serviços ambientais que ele oferece para o homem, foi criada em 2012 a Rede de Pesquisa Campos Sulinos, que tem apoio do Conselho Nacional de Desenvolvimento Científico e Tecnológico $(\mathrm{CNPq})$ e é composta por mais de 20 instituições do Rio Grande do Sul, Paraná e Santa Catarina. Entre as pesquisas realizadas estão levantamentos de grupos de espécies, análise dos impactos das mudanças climáticas nos campos nativos, entre outras. Um desses estudos indicou, por exemplo, que manejos pastoris conservativos da biodiversidade aumentam a resiliência dos ecossistemas campestres, contribuindo, assim, para a adaptação dos sistemas produtivos pecuários às mudanças climáticas. 
